\title{
DEVELOPING READING HANDBOOK BASED ON GENRE BASED APPROACH FOR ISLAMIC SENIOR HIGH SCHOOL LEVEL
}

\author{
Kholifatur Rosyidah \\ MA Queen Zam Zam Pasuruan \\ Rasyidah Nur Aisyah \\ STKIP PGRI Pasuruan \\ Email : ocicyah@gmail.com
}

\begin{abstract}
The purpose of the study was intended to develop supplementary reading material based on genre text for students in the tenth grade of Senior High School in order to help the learners in comprehending and interesting to study about Islamic story. This research was conducted by validation product by the experts, and try out. This research showed that the validation product by the experts showed $80 \%$ the product was appropriate, and the try out by the students were more than expected interval $(100 \%-76 \%)$. To find out whether the effective of the product, the writer gives the students pretest before implementing the product and posttest after implementing. The finding shows that the t-test calculation from the result of pre-test is $23 \%$ and post-test which on is $80,7 \%$. The result of this study concluded that the product was effective to use.
\end{abstract}

Keywords : Genre Based Approach, Development, Supplementary Reading Material.

\section{INTRODUCTION}

Among the four English skills, reading is explained by several educational experts and several studies to have many benefits. Harmer (2007a) stated that reading is useful for language acquisition. In line with Harmer, ( $\mathrm{Lu}$ 2002) mentioned that reading is the foundation of all other skills in language learning. In addition to that, Burn (1996) quoted in (Ihsan 2011) explained that every aspect of life involves reading, both for enjoyment and for obtaining knowledge. In education field, the process of learning which needs reading a lot as the demand of education system.

In Indonesia, the teaching of reading is based on the guidelines issued by Board of the National Standards of Education or locally termed as Badan Standar Nasional Pendidikan (BSNP). Prior to this aim, skills in reading texts are taught in the hope that the students can understand the meaning of written texts. One of the reading skills mentioned in the curriculum of tenth grade in Senior High School in determining the stated and unstated details of the text.

The teaching of reading mostly focuses on the comprehension of various text types, including recount, narrative, procedure, descriptive, spoof, review, news item, analytical exposition, hortatory exposition, anecdote, explanation and report. These types of texts are ten times labeled as genre-based reading. In this research, the researcher only focuses on text types based on the syllabus and curriculum in the Islamic school which the content in the text types are about Islam.

Based on need analysis in Islamic Senior High School (Madrasah Aliyah) in East Java-Indonesia, the supplementary reading materials were developed on students' need and school recommendation, in line with standard competence and basic competence from syllabus. In addition, in Islamic Senior High School (Madrasah
Aliyah) that the English reading material used in this school is same with the book in other state school, they only use general book. There is not any specific reading material that is point to religion and reading genre text. They contain interesting reading passages through colorful pictures. Comprehending supplementary reading materials based on genre based approach in English is not easy. It needs more time to catch what the exactly information of the text. Another crucial problem in teaching and learning English is dealing with the limited learning materials. In Islamic Senior High School (Madrasah Aliyah) in East Java, the English teacher reveals that to find a suitable and interesting learning material for the students is hard to conduct. Considering the vast benefits of reading skills, there should be more time allocation for the students to have exposure to read before they can use it in their real need at school Cotteral in Harmer (2007b). Students are supposed to understand not only the content but also the vocabulary items and generic structure of the text that follow the reading. It is the teacher's responsibilities to motivate the students to be interested in reading by selecting the appropriate materials and especially for the early stages of learning (Alyousef 2005). (Macalister 2007) states that students like to use their free time for activities rather than reading. Many of them think that reading is bored and wastes time. So, it implies the reason why the factors that make reading is difficult never be solved. The researcher use supplementary reading materials based on genre based approach because it is increase knowledge for the students about the various text types. In addition, they will be easier to understand the text on supplementary material.

Therefore, it is needed to develop supplementary reading materials that is suitable to students need and it is expected the supplementary reading material. To make student easier to understand the text, the reading material should be organize well. In developing this supplementary 
reading material, the researcher applies the design of genre based approach. It is also suitable for the school especially for tenth year students that use curriculum 2013.

So, the problem can be formulated as follow "What is the appropriate of supplementary reading materials which is comprehensible for tenth grade of Islamic Senior High School level?"

\section{METHOD}

This research is methodically designed as Research and Development (R\&D). Gall, (Borg and Gall 1984) define Research and Development (R \& D) as a development model in which the findings of the research are used to develop new products and procedures that meet specified criteria of effectiveness, quality, or similar standards through systematic fieldtests, evaluations, and revisions. Here, the writer should consider teaching learning procedures and processes as well as the products. Moreover, (Borg and Gall 1984) state that $\mathrm{R} \& \mathrm{D}$ is a process that is used to develop and validate educational products. To reach the goal in developing supplementary English reading materials for Tenth Grade students of Islamic Senior High School, some steps in R \& D were used. In this research, the researcher adopt the steps of R\&D that provide by Borg and Gall in 1989. Here the details of the research and development model design by Borg and Gall (1989:789795). The eight steps in the R \& D cycles are: (1) need analysis (in Borg and Gall's model it is called research and information collecting); (2) developing material (it is planning and developing preliminary form of the product); (3) Experts' validation; (4) First revision (main product revision); (5) Try-Out (main field testing); (6) Revision (operational product revision); and (7) the final product; (8) Dissemination and implementation.

\section{Need Analysis}

In the first developmental stage, need analysis was carried out. Need analysis or need assessment is defined as the process of identifying and evaluating needs in a community or other defined population of people ((Tomlinson and Masuhara 2011). In this particular study, however, need analysis was conducted to obtain as much information as possible in any given situation in the field. The information from the students and teachers related to the area of the study was surely needed as the basis to develop suitable materials for the students. To obtain the data in need analysis, the researcher employed two kinds of research instruments.

First, the researcher distributed the questionnaire to the students of tenth graders. Thirteen students participated in answering the questionnaire. There were three questions which had to be answered by the students. Seven questions were in the form of open-ended questions, so the students can answer freely according to their experience. Two questions were in the form of multiple choice in which the students were allowed to choose more than one answer. The questionnaire were arranged by using Bahasa Indonesia due to the sample were the tenth graders so that it will be easy and understandable to fill in the questionnaire. Yet, the researcher also gave the explanation about the purpose of giving questionnaire and how to answer it so that it will be easier for them to complete the questionnaires. The questionnaires were intended to find out: (1) the students reading skill and 2) the student interested of reading material based on genre based approach.

The second, the researcher also conducted an interview with the teacher. This interview was intended to get the information about the teachers' teaching method and instructional media he used in the class, the students' characteristic and the teaching learning problems that the teacher had faced, and the teacher's opinion about the idea of developing an instructional medium for speaking that would be developed by the researcher. The researcher presented 12 questions to the teachers which are: (1) experience of teaching, (2) teachers' educational background, (3) teaching frequency, and (4) the teacher's effort in teaching English. After the researcher knew what the problem and the students' need, the researcher stated the objective of creating a new product to solve the problem so that the students can enjoy and increase their motivation to learn English especially for reading ability. Then, the process continued into selecting the method, medium and material that would like to be used. Here the researcher has to adjust the students' needs so it would get the language skill that would be achieved.

\section{Developing Material}

The next step to carry out was material development. To begin with, the researcher designed the mapping of the worksheet reading materials. The mapping largely covers the examples of the text . The texts were mostly adapted from web-based resources. After selecting the texts, several types of exercises were developed, including True/False Questions, WH-Questions, and Arranging Paragraphs. These question-types basically have two different functions, they are: (1) the exercises are to clarify the organization of the passage. The questions mostly deal with the function of the passage, general organization, rhetorical organization, and (2) the exercises are to clarify the contents of the reading passage. The questions are in the form of direct reference (plain fact), inference (implied fact), and evaluation.

\section{Experts' Validation}

The draft of supplementary materials development is focused on reading activity. It was developed reading material based on genre based approach that suitable to their curriculum where they used curriculum 2013 and arranged based on the standard competence and basic competence of the syllabus at Islamic Senior High School especially in tenth grade. The supplemntary materials included three chapters and the objective of the topic was stated at the beginning. The topics content were chosen under the consideration that is relatedto the students' need and interest, teacher's suggestion and also 
syllabus. Those three chapters are narrative text, recount text and song text.

Subsequently, the step was concerned with the expert validation. This phase dealt mostly with obtaining constructive comments from the experts for the improvement of the product. The expert to validate the product are an English lecture of STKIP PGRI Pasuruan, an expert of graphical design, English teacher and the students at MA Queen zam-zam Pasuruan East Java Indonesia.

\section{Table 1. The Expert Validation}

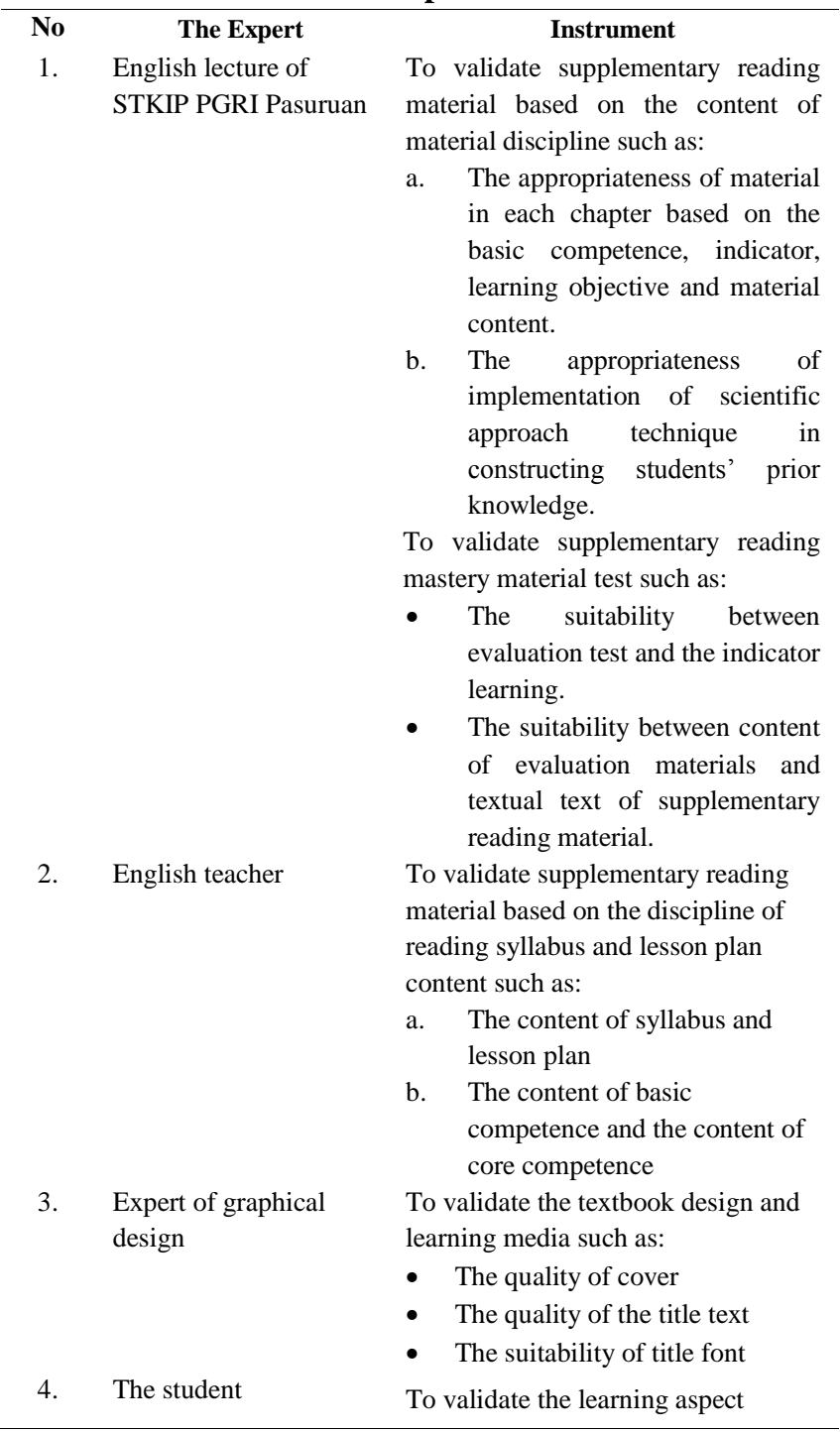

\section{First Revision}

The next step of the research was first revision. When the first draft was ready, the researcher consulted it to the experts in order to be evaluated to make sure that the worksheet materials are valid to be applied to the students. All of suggestions from the experts for these developed materials were very useful in order to make these developed materials better. All of aspects concerning with weaknesses of the developed worksheet materials had been redesigned based on the suggestions and had been validated by both of experts. Then, the materials are improved and ready to be tried out.

\section{Try-Out}

In order to obtain the empirical validity of the material, the researcher conducted try out and because of the limitation in the form of time and permission. The researcher only conducted try out for one unit of Narrative text, one unit of Recount text and one unit of descriptive (Song lyric) with three meetings. It is needed to apply the product in real field where this step carried out some information related to the materials that need to be improved in order to know the appropriateness of the developed materials from practical aspect. To conduct the try-out, the researcher distributed the supplementary reading materials to the students of tenth grade at Islamic Senior High School of Queen zam-zam Pasrepan, Pasuruan. The students were given three meets to read and do the exercise of the materials. After they finished reading the materials and completed all the tasks, they were asked to put a check mark $(\sqrt{ })$ on a checklist asking (questionnaire) their comments and suggestions about the materials. The checklist includes the following items: (1) variety with the idea that the materials should be attractive for the students so that they can enjoy reading; (2) suitability of the content focuses on the variety of the topic whether it is appealing for the students; (3) readability discusses the notion that the materials should be at the right level of difficulty for the students of the tenth grade.

\section{Final product}

The final product of this research is a supplementary reading material book based on genre based approach. The materials are developed based on the fact that reading genre text are interest and important to be learnt, based on the students' needs analysis, and on the narrative, recount and song syllabus as well. The learning objectives are exploring the reading skills, like scanning, skimming, and finding references.

\section{Dissemination and implementation}

The last step is dissemination and implementation. The researcher will give the supplementary reading book (product) for Islamic Senior High School of Quen zamzam Pasrepan, Pasuruan especially for the English teacher in order that completely the worksheet reading before.

The study was carried out at Islamic Senior High School of Quen zam-zam Pasrepan, Pasuruan. The target students of this research were the tenth graders students, they were chosen as the subject because of the basic competence as stated in Senior High School's syllabus based on K13 curriculum, narrative, recount and song text are taught to the tenth grader students.

According to (Latief 2012) in Research and Development, there is no need to have subheadings on data, data collection, instruments, and data analysis. But for this research, the researcher will be use table validation to validating product, observation checklist for the students, interview for the teacher. 
Table 2. The Research Instrument

\begin{tabular}{|c|c|c|c|}
\hline Instrument & $\begin{array}{l}\text { Aspect which } \\
\text { is measued }\end{array}$ & $\begin{array}{l}\text { Data which is } \\
\text { gained }\end{array}$ & Subject \\
\hline $\begin{array}{l}\text { Suuplmentary } \\
\text { reading } \\
\text { materials } \\
\text { validation } \\
\text { sheet }\end{array}$ & $\begin{array}{l}\text { Supplementar } \\
\text { y reading } \\
\text { materal } \\
\text { validity }\end{array}$ & $\begin{array}{l}\text { Supplementar } \\
\text { y reading } \\
\text { materal } \\
\text { validity }\end{array}$ & $\begin{array}{l}\text { Materials } \\
\text { content } \\
\text { expert, } \\
\text { Language } \\
\text { expert, } \\
\text { materials test } \\
\text { expert and } \\
\text { product } \\
\text { design expert. }\end{array}$ \\
\hline $\begin{array}{l}\text { Learning } \\
\text { implementati } \\
\text { on } \\
\text { observation } \\
\text { sheet }\end{array}$ & $\begin{array}{l}\text { The } \\
\text { supplementar } \\
\text { y reading } \\
\text { material } \\
\text { practically }\end{array}$ & $\begin{array}{l}\text { Teacher's } \\
\text { activity }\end{array}$ & Teacher \\
\hline $\begin{array}{l}\text { Learners' } \\
\text { activity } \\
\text { observation } \\
\text { sheet }\end{array}$ & $\begin{array}{l}\text { The } \\
\text { supplementar } \\
\text { y reading } \\
\text { materials } \\
\text { effectiveness }\end{array}$ & $\begin{array}{l}\text { Learners' } \\
\text { activity }\end{array}$ & Learners \\
\hline $\begin{array}{l}\text { Learners' } \\
\text { questionnare } \\
\text { shet }\end{array}$ & & $\begin{array}{l}\text { Learners' } \\
\text { response }\end{array}$ & Learners \\
\hline Test items & & $\begin{array}{l}\text { Material } \\
\text { mastery }\end{array}$ & Learners \\
\hline
\end{tabular}

(Adapted from Parta, 2009)

The researcher will be use checklist table to know the opinion of English teacher as the expert about validation of product. The checklist table for the expert consist of 4 aspects scores descriptions; there are poor (1), good (2), very good (3), and excellent (4). The scores are 4 if all of the main points in the criteria of evaluation are well, scores 3 if The main points in the criteria of evaluation are covered but fail to cover one particular point, scores 2 if several main points in the criteria of evaluation are covered, scores 2 if Only some of the criteria of evaluation are covered, scores 1 if Only some of the criteria of evaluation are covered.

The researcher used observation checklist to know the opinion of the students about English reading material. The observation checklist for the students consist of 8 questions, 3 questions are about the students interesting in reading, 3 questions are about the students background knowledge about reading genre text, 2 questions are about their opinion of development reading material.

The researcher used interview to know the experience of English teacher, educational background, teaching frequency, the teachers' effort in teaching and the opinion about supplementary reading materials based on genre based approach.

A technique of data analysis which was used in this study is descriptive percentage analysis. First, the researcher used descriptive percentage analysis techniques to analyze the data from the students' questionnaire in need analysis, teacher and expert validation questionnaire, and the students' questionnaire for try-out.

Here is the formula to analyze the quantitative data.

The formula to analyze each students' evaluation in the try-out.

$$
\begin{aligned}
& P=\frac{Y}{\mathrm{Z}} \times 100 \% \\
& \mathrm{P}=\text { the percentage of each students' } \\
& \quad \text { evaluation in the try-out stage } \\
& \mathrm{Y} \quad=\text { the total students of each question } \\
& \mathrm{Z} \quad=\text { the total maximum students } \\
& 100=\text { the Constanta }
\end{aligned}
$$

\section{RESULT AND DISCUSSION}

The result of need analysis described into two kinds. First, the result described from the students' questionnaire. Second, the result described from the English teacher's interview. The aim in conducting need analysis was to know the students' and teacher's perspective about learning process so that the researcher can develop appropriate instructional media based on the existing problem in learning activities. Need analysis is important stage in the research and development study because the researcher can identify and analyze the difficulty that has been faced by the students, so the researcher can help them by making an appropriate instructional medium.

In conclusion, the result of interview with the English teacher of the school proved the main problems in English reading materials because the material are not familiar for students and there is no supplementary reading material based on Genre Based Approach, so they have some difficulties for understanding the material. In this case, the teacher agrees with the researcher's idea that developing supplementary reading book based on Genre Based Approach as an instructional reading material. The need analysis was conducted on April 25, 2018. There were 26 tenth grade students who filled the observation checklist for the need analysis. The researcher obtained information about the students interesting in reading and student familiarity with Genre Based Approach. In conclusion based on finding of the observation checklist is the students' interest in learning reading based Genree text to be developed because there is no supplementary reading book based on Genre text for reading material in previous book and they stated that they need those materials. In developing product, the researcher make worksheet reading book based on genre text on Curriculum 13 .The draft of worksheet materials development is focused on reading activity. It was developed based on genre text that suitable to their curriculum where they still used curriculum 13 and arranged based on the standard competence and basic competence of the syllabus. The worksheet materials included three chapters in observing, questioning, experimenting, associating and networking. In each chapter followed by using vocabulary table, essay test, and sometimes find the synonym and the topics content were chosen under the consideration that is related to the students' need and interest, teacher's suggestion and also syllabus. Those three chapters are narrative text, and recount text and descriptive text (songs lyric).

The standard competence and basic competence of reading for the tenth grade students stated in this syllabus 
are used as the basis in arranging the developed materials in this research.
The author organized a mapping material as a guide to make a systematic content of material. The mapping material is shown in the Table 4.1

Table 4.1 Material Mapping

\begin{tabular}{|c|c|c|c|c|}
\hline No & Genre & Topic & Activities & Competence and learning objective \\
\hline 1. & Narrative & Sunan Kalijogo & $\begin{array}{l}\text { - } \text { Getting started } \\
\text { - } \quad \text { Brainstorming; } \\
\text { - } \text { Reading activities; } \\
\text { - Expansion let's have fun } \\
\text { independent construction of text } \\
\text { Muslim Corner; } \\
\text { - } \quad \text { Reading comprehension task; } \\
\text { - Expansion generic structure and } \\
\text { language features of narrative } \\
\text { text; } \\
\text { Reflection. }\end{array}$ & $\begin{array}{l}\text { a. Students will be able to comprehend narrative } \\
\text { text; } \\
\text { b. Students will be able to identify the structure of } \\
\text { narrative; } \\
\text { c. Students will be able to respond to the } \\
\text { narrative text in some kinds of form; } \\
\text { d. Students will be able to read aloud narrative } \\
\text { text with good pronunciation; } \\
\text { e. Students can answer the reading } \\
\text { comprehension questions.Getting started } \\
\text { Brainstorming; }\end{array}$ \\
\hline 2. & Recount & $\begin{array}{l}\text { My Islamic } \\
\text { Boarding School }\end{array}$ & $\begin{array}{l}\text { - } \text { Getting started } \\
\text { - } \text { Brainstorming; } \\
\text { - } \quad \text { Reading activities; } \\
\text { - Expansion let's have fun } \\
\text { independent construction of text } \\
\text { Muslim viewpoint; } \\
\text { - } \text { Expansion generic structure and } \\
\text { language features of recount text; } \\
\text { Reflection. }\end{array}$ & $\begin{array}{l}\text { - Students will be able to compre-hend } \\
\text { recount text; } \\
\text { - Students will be to identify the } \\
\text { characteristic of recount text; } \\
\text { - Students will be able to respond to the } \\
\text { recount text from various kinds of form; } \\
\text { - Students can answer the read-ing } \\
\text { comprehen-sion questions. }\end{array}$ \\
\hline 3. & $\begin{array}{l}\text { Descriptive } \\
\text { (Song Lyric) }\end{array}$ & $\begin{array}{l}\text { Open Your Eyes } \\
\text { (By: Ma-her Zein) }\end{array}$ & $\begin{array}{l}\text { - Getting started Brainstorming; } \\
\text { - } \quad \text { Expansrehend song lyric; } \\
\text { lan-guage features of descriptive; } \\
\text { - } \quad \text { Reflection. }\end{array}$ & $\begin{array}{l}\text { a. Students will able to comprehend the song } \\
\text { lyric; } \\
\text { b. Students will be able to respond to kinds of } \\
\text { song lyric. }\end{array}$ \\
\hline
\end{tabular}

(Adapted from parta, 2009)

After finishing the draft of the developed supplementary reading material, the researcher validates the draft to the experts. The researcher chooses on of English lecture of STKIP PGRI Pasuruan as the first expert. First valuator was focused on covered material content and material test. For the evaluation of the content, the ex-pert said the developed materials are good and appropriate to be implemented in teaching and learning process of English reading. But, the lecturer said that the Islam-ic story is too much and the researcher asked to make only one Islamic story and the developer have to develop the questions.

This learning media trial was conducted with the aim to find out the weakness of the product which has been made or develop to know the effectiveness of the product when it was used by the students' target. In this step, the researcher had two tests to know the effectiveness of the worksheet for the students which were; pre-test and posttest. The researcher conducted the supplementary reading material to the 10th grade students. Before using the product, the researcher gave a pre-test to the students in order to know how deep the students understand in reading comprehen-sion. The next step of the researcher was revision of the product after validated by the expert. After finishing the draft of the developed supplementary reading material, the researcher validates the draft to the experts. For the evaluation of the content, the expert said the developed materials are good and appropriate to be implemented in teaching and learning process of English reading. But, the teacher also said that the Islamic story is too much and the researcher asked to make only one Islamic story and the developer have to develop the questions such as: find some difficulties vo-cabulary, find the synonym and etc.

After all the phase has been past, the developed materials were completely developed. The final product of this development was accommodated for the tenth grade on second semester of Senior High School program especially by the same characteristics school. The supplementary reading material is completely arranged entitle "supplementary reading material based Genre Based Approach". The supple-mentary reading material contained of three chapters (narrative, recount and descrip-tive text"song lyric"). This supplementary reading material is developed based on students need, school recommendation and it was arranged based on standard compe-tence and basic competence from syllabus. Interesting reading passage with Islamic theme message was designed not only for improving student's quality in reading but also to create Feeling love to Islamic history attitude. The text also completed by col- 
orful pictures with related to the topic on hope that it can attract student's interest to reading and the researcher also inserted some various strategies of reading in order to increase student's comprehension skill and to check their mastery in reading compre-hension as well as to show their competence this supplementary reading material also provided some various exercises such as multiple choice, completion, essay, etc.

After the researcher re-designn all of the material content and material mas-tery test based on the expert validation and the result of the try out, then the researcher give the supplementary reading material (product) especially for English teacher in order to completely the worksheet reading before. In addition, the English teacher can use and teach the product to students in every meeting. So, the students can improve and enrich their knowledge about Islam.

\section{CONCLUSION}

The product in the form of supplementary reading material contains about the material that is devoted to Islamic learners of tenth grade in Islamic Senior High School. The material presented is not as detailed as it should be. However, other de-veloper's purpose is that by the existing instruction will be able to make learners construct their prior knowledge especially in reading acticity.

While the function of the product supplementary reading material is as a facil-ity and the foundation of the learners to build their creativity and intellectual. The instruction in the material made, deliberately made a bit challenging, so that learners feel challenged to learn, and this is also the developer's goal for learners to build their prior knowledge especially in reading activity. The resulting product in the form of supplementary reading material is a textbook that refers to the Islamic theme and genre approach. This supplementary reading material has a chapter. In each chapter there is a narrative, recount and song text. This will make teachers and learners easier to implement learning.

Based on the results of analysis of the implementation of learning in term of validity test, in this case the value obtained is high and is said to be a valid, practical and effective product. The supplementary reading material based on genre based approach is suitable to be used for the students to leam reading especially in narrative, recount and song text. It has been validated by the English teacher as the expert, and has been try-out 2 times. Based on the assessment of English teacher as the expert, it shows that the of competences, basic of competence, research and information collecting for tenth grade of senior high school, and it has been developed "suitable" be used as a source of learning.

In addition, the supplementary reading material based on genre based ap-proach has some weakness and strengthens. Because of the limited time in the school, there are some weaknesses of the supplementary reading material such as: the limited text of some chapter and the limited explanation of narrative, recount and descriptive text. and also there are some strengthens of the supplementary reading material such as: the specific text which use the Islamic story which make the student easier to comprehend the text and beautiful picture, colour and different font.

\section{REFERENCES}

Alyousef, H. 2005. "Teaching Reading Comprehension to ESL/EFL Learners. The Reading Matrix. Vol. 5, No 2." Retrieved October 24: 2014.

Borg, Walter R, and Meredith D Gall. 1984. "Educational Research: An Introduction."

Harmer, J. 2007a. How to Teach English. Essex: Pearson Longman.

Harmer, J.2007b. The Practice of English Language Teaching.4thEd.Essex:Pearson Longman.

Ihsan, Moh Zainul. 2011. "Improving The Reading Skill of The Eleventh Graders of MAN 6 Jombang Through Reciprocal Teaching Technique.(Thesis)." DISERTASI dan TESIS Program Pascasarjana $U M$.

Latief, Mohammad Adnan. 2012. "Research Methods on Language Learning: An Introduction.” Malang: Universitas Negeri Malang.

Lu, Zhongshe. 2002. "Readability in Reading Materials Selection and Coursebook Design for College English in China."

Macalister, John. 2007. "Implementing Extensive Reading in an EAP Programme." ELT journal 62(3): 248-56.

Tomlinson, Brian, and Hitomi Masuhara. 2011. Research for Materials Development in Language Learning: Evidence for Best Practice. Bloomsbury Publishing. 